\title{
EFFECT OF HUMAN RELATIONS AND INTEGRITY ON ORGANIZATIONAL PERFORMANCE THROUGH ORGANIZATIONAL CITIZENSHIP BEHAVIOR IN PT. HANA NUANSA PRATAMA
}

\section{Esthi Budiyanti}

Universitas Krisnadwipayana

Po Box 7774 / Jat Cm Jakarta, Indonesia

Email: esti.budhi@gmail.com

Indonesia

\section{Abdul Rivai}

Universitas Krisnadwipayana

Po Box 7774 / Jat Cm Jakarta, Indonesia

Email: abdulrivai@ unkris.ac.id

Indonesia

\section{Djoko Setyo Widodo}

Universitas Krisnadwipayana

Po Box 7774 / Jat Cm Jakarta, Indonesia

Email: djokosetyowidodo@gmail.com

Indonesia

\section{Abstract}

This study aimed to determine the effect of human relations and the integrity of the organization's performance simultaneously, determine the effect of human relations to organizational performance partially, determine the effect of the integrity of the performance of an organization partially, determine the effect organizational citizenship behavior to organizational performance partially, determine the effect of human relations to organizational performance through organizational citizenship behavior and determine the effect of integrity to organizational performance through organizational citizenship behavior. The study was conducted in PT Hana Nuansa Pratama. Sampling using saturated samples involving 70 employees in all parts of the organization. Analysis of data using path analysis.

Based on data analysis known that the human relations and integrity variables affect the performance of the organization simultaneously. Human relations variables affect the performance of an organization partially. Integrity variables affect the performance of an organization partially. Organizational citizenship behavior variables affect the performance of an organization partially. Organizational citizenship behavior can provide an increased impact on human relations and the integrity of the performance of the organization.

\section{Keywords: Human relations, integrity, organizational citizenship behavior, organizational performance}

\section{Introduction}

The study on the factors that affect the performance of the organization is mostly done at present. Assessment of the performance of the organization is an activity comparing the actual results obtained with the plan. One of the factors affecting the performance of the organization is human relations. Human relations are a key condition for the success of good communication between private communication and communication within the agency. Mastery in creating human relations within the company or agency employees will greatly assist a leader in helping communications vertical and horizontal communication. On the other hand, an employee human relations human relationship that is always needed by employees, where it functions as a personal being and a social being, the need for others to cooperate in achieving the goal of his life. 
The human relationship is communication because of its orientation on behavior, it contains activities to change attitudes, opinions, or behavior (Onong,2001). Human relations are the interaction between a person with others both in work situations or in the organization of the workmanship. Judging from his leadership, in charge of a group is the interaction of people towards work situations that motivated to work productively, thus achieved the satisfaction of economic, psychological and social. People who own integration will not be deterred by the temptation to betray the moral values that are believed. Personal motivation is the person who maintains the level of honesty and high ethics in words and actions every day. They are the ones who are competent, conscientious and reliable in the act, it can be trusted by his colleagues, subordinates, and superiors as well as outsiders. They also treat others fairly.

Other factors that affect the performance of the organization is integrity. Integration is acting consistent with the values and policies of the organization as well as the code of professional conduct, even in a state that is difficult to do so. Simply put, motivation showed firmness attitude, merging deeds and moral values embraced by someone.

People who have integration will not be deterred by the temptation to betray the moral values that are believed. Personal motivation is the person who maintains the level of honesty and high ethics in words and actions every day. They are the ones who are competent, conscientious and reliable in the act, it can be trusted by his coworkers, subordinates, and superiors as well as outsiders. They also treat others fairly.

Awaludin, Adam, and Maharani (2016) examined the effect of the integrity of the performance of the organization. This research was conducted at a government hospital in Kendari. The study states that integrity affects the performance of the organization. Organizational citizenship behavior is also expected to affect the performance of the organization. Organizational citizenship behavior is also known as organizational citizenship behavior is a behavior in which someone is willing to do anything beyond what has been described by his work, and did not have an appreciation for it. For example, OCB, if there is a worker who is willing to help his boss or coworkers to do the job that is not in his contract, then the person is said to have a good OCB.

\section{Literature Review}

\section{Human Relationship}

Human relations a key condition for the success of good communication between private communication and communication within the agency. Mastery in creating human relations within the company or agency employees will greatly assist a leader in helping communications vertical and horizontal communication. On the other hand, an employee human relations human relationship that is always needed by employees, where it functions as a personal being and a social being, the need for others to cooperate in achieving the goal of his life. A harmonious relationship will create a pleasant working atmosphere, and this will affect the spirit servants in carrying out any work.

According to Davis (2001), Human relations is the interaction between a person with others both in work situations or in the organization of the workmanship. Judging from his leadership, in charge of a group is the interaction of people towards work situations that motivated to work productively, thus achieved the satisfaction of economic, psychological and social. There are two senses of human relationships, human relations in a broad sense and human relations in the narrow sense:

1. Human relations in a broad sense. Human relations in the broadest sense is the interaction between a person with others in all circumstances and all areas of life. Thus, human relations did anywhere; it can be done at home, on the street, in public transport (eg bus, train) and so on.

2. Human relations in the narrow sense. Human relations in the narrow sense is also the interaction between a person with another person.

However, the interactions here are in work situations and work for an organization. Barriers between humans generally have two properties, namely the objective and subjective. Barriers that are objective is interference and obstacles on the course of human relations unintentional and made by other parties but may be caused by unfavorable 


\section{(C) Center for Promoting Education and Research (CPER) USA}

www.cpernet.org

\section{circumstances.}

Barriers subjective nature of which are intentionally made by others so it is a nuisance, opposition to a communication effort. Basic disorder and this opposition are usually due to a conflict of interest, prejudice, greed, envy, apathy and so on (Onong, 2001). Human Relations is one of three approaches to communicate within the organization. Because in organizing not only emphasize on productivity and accomplishments,

\section{Integrity}

Integrity comes from the Latin "integrate" which means complete or flawless, perfect, without a visor. The point is what is in the hearts of the same with what we think, say and do (Bertens,1994). So, we can say that integrity is a consistent attitude and behavior to uphold work ethics and professional ethics. Integration requires the temptation or opportunity to commit misconduct. However, people who are not motivated misconduct because he had confidence in the importance of upholding the noble values in their environment.

Integration is acting consistent with the values and policies of the organization as well as the code of professional conduct, even in a state that is difficult to do so. Simply put, motivation showed firmness attitude, merging deeds and moral values embraced by someone.

People who own integration will not be deterred by the temptation to betray the moral values that are believed. Personal motivation is the person who maintains the level of honesty and high ethics in words and actions every day. They are the ones who are competent, conscientious and reliable in the act, it can be trusted by his coworkers, subordinates, and superiors as well as outsiders. They also treat others fairly.

\section{Organizational Citizenship Behavior (OCB)}

Organizational Citizenship Behavior (OCB) is a behavior that is not part of the task that has been formally required for an employee but overall encouraging the effective functioning of the organization (Robbins,2010). In terms of the effectiveness of the organization, individuals in a team need to have behaviors that support them. Such behavior is not only Appropriate behavior is only a role but is expected to bring extra-role behavior of the individual so that the fabric can be more solid teamwork and can work optimally for the organization (Bennet,1979). In addition to the above definition. Podsakoff, (1997) also provides reviews of those five dimensions of organizational citizenship behavior (OCB):

Altruism: behaviors that influence helping colleagues in charge.

1. Conscientiousness: Becomes part of the behavior that the employees who carry out tasks that exceed the minimum requirements.

2. Sportsmanship: the feelings of the employees to refrain from complaints about things that are not preferable.

3. Courtesy: the behavior of the individual parts to replace others in the organization about changes affecting Reviews their work.

4. Civic virtue: Becomes part of the behavior that individuals who indicated resources that they participate in the company.

Organizational behavior (OB) or commonly called also the behavior of the organization is science that studies human behavior in an organization and how that behavior has an impact on the behavior of the member's institution. Reviews these impacts are or organizational citizenship behavior (OCB).

In the end, OCB becomes a variable in organizational behavior. Organ defines that OCB is free behavior of individuals that are explicitly or indirectly recognized by the formal system, and in the aggregate function effectively and efficiently in an organization. Understanding OCB as proposed by the Organ is as follows:

Organizational citizenship behavior: discretionary individual behavior, not directly or explicitly recognized by the formal reward system, and in the aggregate promotes the efficient and effective functioning of the organization. 


\section{(C) Center for Promoting Education and Research (CPER) USA}

WWW.cpernet.org

More Organ effect that the aggregate function is referring to the people in a group, department, or organization. If only one person, OCB does not have a significant impact on an organization, but According to the Organ, if an organization, in the aggregate, its members have a good OCB, its impact on the organization will be felt Significantly. Organ said that helping behavior and compliance are Also included in the definition of OCB itself. Besides, there is another sense of OCB. Griffin \& Moorhead (2013) defined OCB as follows:

Citizenship organization refers to the behavior of individuals who make a positive overall contribution to the organization. Griffin \& Moorhead (2013) said that OCB Refers to the behavior of an individual who had a positive impact on the organization. Griffin \& Moorhead (2013) an example by comparing the two employees who have the same quality in a job. But one of them is not willing to work until late and only want to work following the hours, while one of the others are willing to work late even though it was outside his working hours, he is also willing to help him whenever needed.

The behavior of individuals who freely and spontaneously generated from a person's character or the character of the work or the organization is also derived from the relationship with the boss. This behavior is done to the organization or co-workers, which results in improved organizational effectiveness through the direct influence of the job or the indirect influence of socially-based improvement of interpersonal relationships. Described citizenship behavior is not informal employment, also has no contract awards.

Based on the theories and synthesis that has been discussed in the previous OCB is that the person's behavior where a person knowingly wants to do work beyond reviews their responsibilities or obligations following the contract, it can be arranged an indicator to determine the level of assessment for the OCB. Indicators that can be set are as follows:

1. The Nature of Helping

2. Attitude Sportif

3. Fidelity or Loyalty

4. Compliance with the Organization

\section{Organizational Performance}

According to Richard et al (2010) the performance of the organization is generated by organization that include results (outcomes) that the financial performance such as profit, as measured by return on assets, return on investment and so on, the performance of the market such as the expansion of market share, and sales. Besides the return of shareholders, a return of shareholders and an increase in the economy of shareholders.

In some areas of the organization's performance can also be measured by other things such as strategic planning, operations, finance, legal and organizational development. In developing the institution or organization is a necessity to survive in the competitive world climate.

The purpose of productivity associated with the development of that organization (Shrestha,1997). A small organization that has a desire to continue to grow and become large. The growing organization to the development itself.

Measuring the performance of the organization according to the concept of PBM SIG (the performance-based management special interest group) is to perform monitoring and reporting programs and pay attention to objectives achieved. Performance is measured based on the activities of the program to run, products, and services produced. the effectiveness of the achievement of organizational performance should be able to answer the question:

a. How the project is implemented a well

b. The achievement of organizational goals

c. The satisfaction of consumers who served

d. The process must be controlled

e. development organization 
Besides according to Kaplan and Norton (1992) the organization's performance should be measured in terms of concept not only financially but Also from non-financial. Performance can be measured by productivity, quality, consistency and so on. On the other hand, measure organizational performance outcomes, behavioral and normative level, education and concepts generated Including management development (Richard, 2010).

\section{Research Methods}

\section{Research Design}

This research uses an explanatory analysis approach. This means that each of the variables presented in the hypothesis will be observed by testing the causal relationship of independent variables on the dependent variable. Relationships between variables can be described in terms of the path analysis diagram as follows:

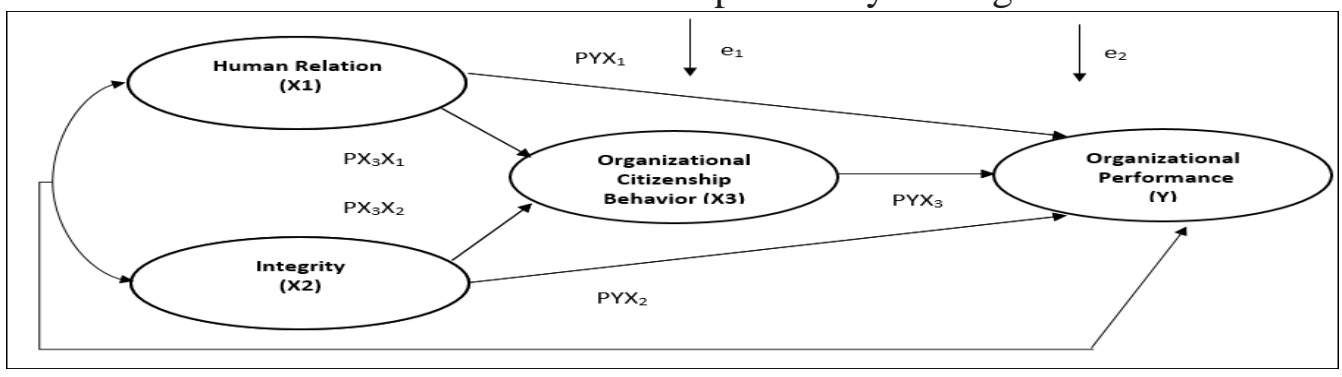

Figure 1. Research Framework

\section{Object of Research}

The study was conducted in PT. Hana Nuansa Pratama. The company is engaged in construction services in power generation, telecommunications distribution network installations, installation of control systems and construction of buildings. The company is located in Rawa Lumbu Bekasi.

\section{Population and Sample Research}

The population is a generalization region consisting of the objects that have a certain quantity and characteristics defined by the researchers to learn and then drawn conclusions (Sugiyono,2014). Samples were towing the majority of the population to represent the entire population, (Surakhmad,2001). The sample used by the author in this study were employees of PT. Hana Nuansa Pratama.

The total number of employees by 70 people. Employees are entirely included in the data analysis. This sampling included in the sample collection by using a purposive sampling method. This sampling is sampling in an analytical unit by taking into account the same characteristics in the samples. Overall samples were taken at the organization's use of saturated sampling.

\section{Research Result}

\section{Effect of Human Relations and Integrity on Organizational Performance}

The linear analysis model can be based on calculations using the SPSS program as follows.

Table 1 Results of the analysis of the first equation

\section{Coefficientsa}

Coefficientsa

\begin{tabular}{|c|c|c|c|c|c|c|}
\hline \multirow{2}{*}{\multicolumn{2}{|c|}{ Model }} & \multicolumn{2}{|c|}{ Unstandardized Coefficients } & \multirow{2}{*}{$\begin{array}{c}\text { Standardized Coefficients } \\
\text { beta }\end{array}$} & \multirow[b]{2}{*}{ t } & \multirow[b]{2}{*}{ Sig. } \\
\hline & & $\mathrm{B}$ & Std. Error & & & \\
\hline & (Constant) & 16.208 & 2,926 & & 5.539 &, 000 \\
\hline & RELATIONS &, 719 &, 131 & 43 & 5.466 &, 000 \\
\hline & INTEGRITY &, 578 &, 082 & 56 & 7.019 &, 000 \\
\hline
\end{tabular}




\section{(C) Center for Promoting Education and Research (CPER) USA}

Based on the tables above, the simultaneous structural equations can be described as follows $\mathrm{Y}=0,438 \mathrm{X} 1+0.562 \mathrm{X} 2$

Table 2. Calculate the $F$ value equations simultaneously ANOVAa

\begin{tabular}{|c|c|c|c|c|c|c|}
\hline Model & & $\begin{array}{l}\text { Sum of } \\
\text { Squares }\end{array}$ & df & mean Square & $\mathrm{F}$ & Sig. \\
\hline & Regression & 1410.670 & 2 & 705.335 & 46.039 & , $000 \mathrm{~b}$ \\
\hline & Residual & 1026.473 & 67 & 15.320 & & \\
\hline & Total & 2437.143 & 69 & & & \\
\hline
\end{tabular}

a. Dependent Variable: PERFORMANCE

b. Predictors: (Constant), INTEGRITY, RELATIONS

Based on the above table it is known that the value $\mathrm{f}$ calculated at 46.039 and significance of 0.00 . This value is less than 0.05. This means human relations and integrity variables affect the performance of the organization simultaneously. The magnitude of the effect of the independent variable on the dependent variable can be seen from the following values of $\mathrm{r}$ squared.

Table 3. Values r squared regression model first

\begin{tabular}{|l|r|r|r|r|r|}
\hline \multicolumn{7}{|c|}{ Model Summaryb } \\
\hline Model & $\mathrm{R}$ & R Square & $\begin{array}{c}\text { Adjusted R } \\
\text { Square }\end{array}$ & $\begin{array}{c}\text { Std. Error of } \\
\text { the Estimate }\end{array}$ & Durbin-Watson \\
\hline 1 &, $761 \mathrm{a}$ &, 579 &, 566 & 3.91414 & 1.222 \\
\hline
\end{tabular}

a. Predictors: (Constant), INTEGRITY, RELATIONS

b. Dependent Variable: PERFORMANCE

Based on the above table it is known that the value of $\mathrm{r}$ squared of $57.9 \%$ means that human relations and integrity variables affect the performance of the organization by $57.9 \%$ while the rest influenced by other variables that are not incorporated into the model equations.

\section{Analysis of Effect of Human Relations on Organizations Performance}

The results of the analysis of the influence of human relations to organizational performance can be partially seen in the following table.

Table 3. The results of the analysis of the second regression equation Coefficientsa

\begin{tabular}{|c|c|c|c|c|c|}
\hline \multirow[b]{2}{*}{ Model } & \multicolumn{2}{|c|}{ Unstandardized Coefficients } & \multirow{2}{*}{$\begin{array}{c}\text { Standardized Coefficients } \\
\text { beta }\end{array}$} & & \multirow[b]{2}{*}{ Sig. } \\
\hline & $\mathrm{B}$ & Std. Error & & & \\
\hline $1 \quad$ (Constant) & 26.044 & 3,359 & & 7.753 &, 000 \\
\hline RELATIONS & 851 & 170 & 51 & 5.004 & 000 \\
\hline
\end{tabular}

a. Dependent Variable: PERFORMANCE

Structural equation of the above data can be seen as follows: $\mathrm{Y}=0.519 \mathrm{X} 1$

Based on the chart above analysis it is known that the human relations coefficient of 0.519. T value of 5.004. The significant value of 0.00 . The significance value smaller than 0.05 . This means that human relations variables affect the performance of an organization partially. The magnitude of the effect of human relations to organizational performance can be seen in the following table. 
Table 4. Values r squared second equation

\begin{tabular}{|l|r|r|r|r|}
\hline Model & R & R Square & Adjusted R Square & $\begin{array}{c}\text { Std. Error of the } \\
\text { Estimate }\end{array}$ \\
\hline 1 &, $519 \mathrm{a}$ &, 269 &, 258 & 5.11811 \\
\hline
\end{tabular}

Based On the table above it can be seen $r$ squared value of 0.269 . this means that the effect of variable human relations on the performance of $26.9 \%$ and the rest influenced by other variables not included in the model equations.

\section{Influence Analysis of Integrity on Organizational Performance}

Table 5. Results of the analysis of the third regression equation

\section{Coefficientsa}

\begin{tabular}{|c|c|c|c|c|c|}
\hline \multirow[b]{2}{*}{ Model } & \multicolumn{2}{|c|}{ Unstandardized Coefficients } & \multirow{2}{*}{$\begin{array}{c}\text { Standardized Coefficients } \\
\text { beta }\end{array}$} & \multirow[b]{2}{*}{$\mathrm{t}$} & \multirow[b]{2}{*}{ Sig. } \\
\hline & $\mathrm{B}$ & Std. Error & & & \\
\hline $1 \quad$ (Constant) & 28.769 & 2,162 & & 13.307 &, 000 \\
\hline INTEGRITY & 642 & 097 & 625 & 6,608 & 000 \\
\hline
\end{tabular}

a. Dependent Variable: PERFORMANCE

Structural equation of the above data can be seen as follows $\mathrm{y}=0.625 \mathrm{x} 2$

Based on the chart above analysis it is known that the integrity coefficient of 0.625 . T value of 6,608 . The significant value of 0.00 . The significance value smaller than 0.05 . This means that the integrity of variables affects the performance of an organization partially. The amount of influence the integrity of the organization's performance can be seen in the following table.

Table 6. The third equation $r$ squared

Model Summary

\begin{tabular}{|l|r|r|r|c|}
\hline Model & $\mathrm{R}$ & R Square & Adjusted R Square & $\begin{array}{c}\text { Std. Error of the } \\
\text { Estimate }\end{array}$ \\
\hline 1 &, $625 \mathrm{a}$ &, 391 &, 382 & 4.67176 \\
\hline
\end{tabular}

a. Predictors: (Constant), INTEGRITY

Based on the above table it can be seen $r$ squared value of 0.391 . This means that the integrity of the variables influences on organizational performance of $39.1 \%$ and the rest influenced by other variables not included in the model equations.

\section{Influence Analysis of Organizational Citizenship Behavior on Organizational Performance}

The results of the analysis of organizational citizenship behavior influence the performance of partial can be seen in the following table.

Table 7. Results of the fourth regression equation analysis

Coefficientsa

\begin{tabular}{|c|c|c|c|c|c|}
\hline \multirow[b]{2}{*}{ Model } & \multicolumn{2}{|c|}{$\begin{array}{c}\text { Unstandardized } \\
\text { Coefficients }\end{array}$} & \multirow{2}{*}{$\begin{array}{c}\text { Standardized } \\
\text { Coefficients } \\
\text { beta } \\
\end{array}$} & \multirow[b]{2}{*}{$l$} & \multirow[b]{2}{*}{ Sig. } \\
\hline & $\mathrm{B}$ & Std. Error & & & \\
\hline $\begin{array}{ll}1 & \text { (Constant) } \\
& \text { OCB }\end{array}$ & $\begin{array}{r}8.884 \\
, 807\end{array}$ & $\begin{array}{r}2.469 \\
, 058\end{array}$ & , 858 & $\begin{array}{r}3.599 \\
13,800\end{array}$ & $\begin{array}{l}.001 \\
000\end{array}$ \\
\hline
\end{tabular}

a. Dependent Variable: PERFORMANCE 
Structural equation of the above data can be seen as follows: $\mathrm{Y}=0.858 \mathrm{X} 3$

Based on the chart above analysis it is known that the coefficient of organizational citizenship behavior amounted to 0.858 . T value of 13,800 . The significant value of 0.00 . The significance value smaller than 0.05 . This means that the variable of organizational citizenship behaviors affects the organization's performance partially. The magnitude of the effect of organizational citizenship behavior on organizational performance can be seen in the following table.

Table 8. The valuer squared fourth equation Model Summary

\begin{tabular}{|l|r|r|r|c|}
\hline Model & $\mathrm{R}$ & R Square & Adjusted R Square & $\begin{array}{c}\text { Std. Error of the } \\
\text { Estimate }\end{array}$ \\
\hline 1 &, $858 \mathrm{a}$ &, 737 &, 733 & 3.07090 \\
\hline
\end{tabular}

a. Predictors: (Constant), OCB

Based on the above table it can be seen $r$ squared value of 0.737 . This means that the effect of variable organizational citizenship behavior on organizational performance amounted to $73.7 \%$ and the rest influenced by other variables not included in the model equations.

\section{Analysis of Effect Human Relations on Organizational Performance through Organizational Citizenship Behavior}

Based on the partial path analysis above, it can be described as follows. The analysis is an analysis in line with the structure of this sub-image.

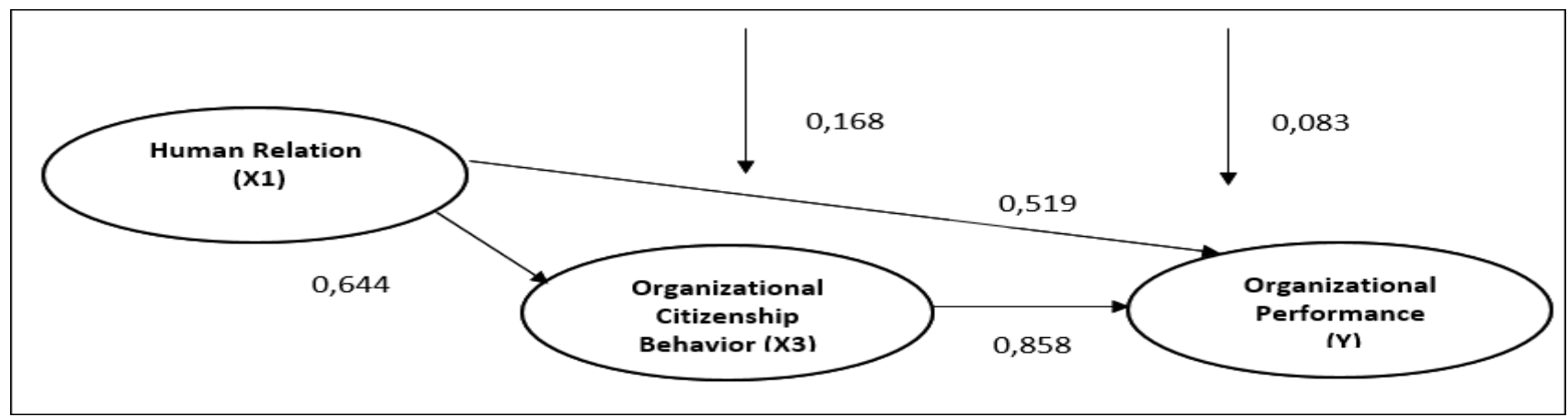

Figure 2. Analysis of the influence lines X1 to Y via X3

Coefficient of human relations influence on organizational citizenship behavior can be seen in the following table

Table 9. Effect of Human relation to organizational citizenship behaviour work Coefficientsa

\begin{tabular}{|c|c|c|c|c|c|}
\hline \multirow[b]{2}{*}{ Model } & \multicolumn{2}{|c|}{$\begin{array}{c}\text { Unstandardized } \\
\text { Coefficients }\end{array}$} & \multirow{2}{*}{$\begin{array}{c}\text { Standardized } \\
\text { Coefficients } \\
\text { beta }\end{array}$} & \multirow[b]{2}{*}{$\mathrm{t}$} & \multirow[b]{2}{*}{ Sig. } \\
\hline & $\mathrm{B}$ & Std. Error & & & \\
\hline $\begin{array}{ll}1 & \text { (Constant) }\end{array}$ & 19.916 & 3.197 & & 6.229 &, 000 \\
\hline $\begin{array}{l}\text { RELATION } \\
\mathrm{S}\end{array}$ & 1,124 &, 162 &, 644 & 6.943 &, 000 \\
\hline
\end{tabular}

a. Dependent Variable: OCB

Based on the picture above can be seen that the influence of human relations to organizational performance is 0.519 . The effect of human relations to organizational performance through organizational citizenship 
behaviour is $0.644 \times 0.858=0.553$. In this case, the indirect effect is greater than the direct effect so that it can be said that the organizational citizenship behaviour variables work as an intervening variable.

\section{Influence Analysis of Integrity on Organizational Performance through Organizational Citizenship Behavior}

Based on the partial path analysis above, it can be described as follows. The analysis is an analysis in line with the structure of this sub-image.

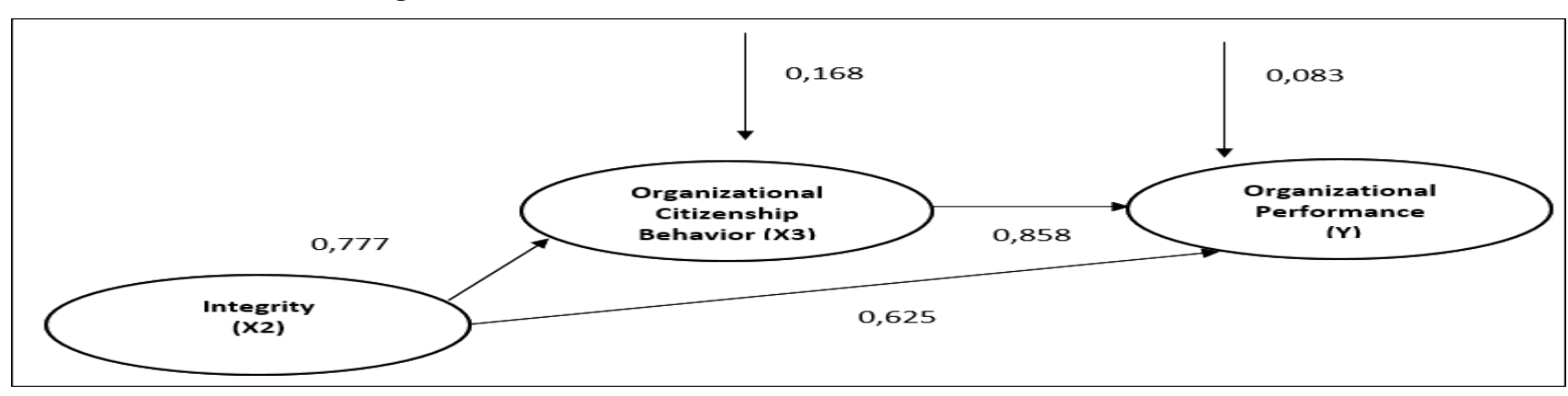

Figure 3. Analysis of the influence lines $\mathrm{X} 2$ to $\mathrm{Y}$ via X3

The coefficient of the integrity of the organizational citizenship behaviour can be seen in the following table.

Table 10. Coefficient of iintegrity influence on organizational citizenship behaviour work Coefficientsa

\begin{tabular}{|ll|r|r|r|r|r|}
\hline \multirow{2}{*}{ Model } & \multicolumn{2}{|c|}{$\begin{array}{c}\text { Unstandardized } \\
\text { Coefficients }\end{array}$} & \multicolumn{2}{|c|}{ Standardized Coefficients } & & \\
\cline { 2 - 7 } & \multicolumn{1}{|c|}{ B } & Std. Error & beta & \multicolumn{1}{c|}{ t } & Sig. \\
\hline 1 & (Constant) & 23.492 & 1,854 & & 12.673 &, 000 \\
& INTEGRITY &, 849 &, 083 &, 777 & 10.191 &, 000 \\
\hline
\end{tabular}

a. Dependent Variable: OCB

Based on the picture above it can be seen that the direct effect integrity on the performance of organizational is 0.625 . While the integrity of the influence on organizational performance through organizational citizenship behavior is 0.777 x $0.858=0.667$. In this case smaller than the direct influence indirect influence so that it can be said that the organizational citizenship behavior variables work as an intervening variable.

\section{Conclusions and Suggestions}

\section{Conclusion}

Human relations and integrity variables affect the performance of the organization simultaneously. F value calculated at 46.039 and the significance of 0.00 . This value is less than 0.05 . R squared value of $57.9 \%$ means that human relations and integrity variables affect the performance of the organization by $57.9 \%$ while the rest influenced by other variables that are not incorporated into the model equations.

Human relations variables affect the performance of an organization partially. $\mathrm{T}$ value of 5.004. The significant value of 0.00 . The significance value smaller than 0.05 . $\mathrm{R}$ squared value of 0.269 . This means that the effect of variable human relations on the performance of $26.9 \%$ and the rest influenced by other variables not included in the model equations.

Integrity variables affect the performance of an organization partially. $T$ value of 6,608 . The significant value of 0.00 . The significance value smaller than 0.05 . $\mathrm{R}$ squared value of 0.391 . This means that the integrity of the variables influences on organizational performance of $39.1 \%$ and the rest influenced by other variables not included in the model equations. 
Organizational citizenship behavior variables affect the performance of an organization partially. T value of 13,800. The significant value of 0.00 . The significance value smaller than 0.05 . $R$ squared value of 0.737 . This means that the effect of variable organizational citizenship behavior on organizational performance amounted to $73.7 \%$ and the rest influenced by other variables not included in the model equations.

The effect of human relations to organizational performance is 0.519 . The effect of human relations to organizational performance through organizational citizenship behavior is 0.644 x $0.858=0.553$. In this case, the indirect effect is greater than the direct effect so that it can be said that the organizational citizenship behavior variables work as an intervening variable.

The direct effect on the integrity of the organization's performance is 0.625 . While the integrity of the influence on organizational performance through organizational citizenship behavior is $0.777 \times 0.858=0.667$. In this case smaller than the direct influence indirect influence so that it can be said that the organizational citizenship behavior variables work as an intervening variable.

\section{Suggestion}

Human relations are the interaction between a person with others both in work situations or in the organization of the workmanship. This relationship needs to be developed to improve the relationship with the boss, customer relationships, and relationships with the community.

Integrity is built on the foundation of the discipline. Integrity is moral strength proved right in the middle of the fire remains a temptation. Integrity also needs to be built to develop the attitude, keep a good name, and implement a system of norms.

Organizational citizenship behavior (OCB) is a behavior that is not part of the task that has been formally required for an employee but overall encouraging the effective functioning of the organization. The behavior can be improved by taking into account the attitude of altruism (happy to help) co-workers, conscientiousness attitude (being part of the work), Sportsmanship attitude (attitude did not complain), the attitude of courtesy (could replace the role) and civic (can participate).

\section{References}

Bertens. (1994). Etika. Jakarta: Gramedia Pustaka.

Effendy, Onong Uchyana, (2001). Dinamika Komunikasi. Bandung: Remaja Rosdakarya

Ishak Awaludin, La Ode Bahana Adam, Sri Wiyati Maharani. (2016). The Effect of Job Satisfaction, Integrity and Motivation on Performance. The International Journal of Engineering and Science. Vo. 5 No 1 Januari 2016. Southeast Sulawesi Indonesia.

Kaplan, R. S., \& Norton, D. P. (1992). The Balanced Scorecard -Measures that Drive Performance. Harvard Business Review.

Keith Davis and Newstrom, John W. (2001). Organizational Behavior-Human Behavior at work. Tenth Edition McGraw-Hill. International Edition, New York.

Lerroy, Bennet A. New Jersey, (1979). International Organization, PrenticeHall Inc

Moorhead, Gregory dan Ricky W. Griffin. (2013). Perilaku Organisasi. Jakarta: Salemba Empat.

P. Robbins, Stephen; Coulter, Mary, (2010). Manajemen, Edisi 10, Jilid 1 dan 2, Penerbit Erlangga. Jakarta.

Podsakoff, P.M., Ahearne, M., \& McKenzie, S.B. (1997).Organizational Citizenship Behaviour and The Quantity and Quantity of Work Group Performance. Journal of Applied Psychology, Vol. 82: 262-270.

Shrestha, Taliziduhu, (1997). Metodologi Ilmu Pemerintahan. Jakarta: Rineka Cipta. 
International Journal of Business and Applied Social Science (IJBASS)

E-ISSN: 2469-6501

VOL: 5, ISSUE: 10

October/2019

DOI: 10.33642/ijbass.v5n10p2

https://ijbassnet.com/

(C) Center for Promoting Education and Research (CPER) USA

WWW.cpernet.org

Sugiyono. (2014). Metode Penelitian Kuantitatif, Kualitatif, dan Kombinasi (Mixed Methods). Bandung: Alfabeta

Winarno Surakhmad. (2001). Pengantar Penelitian Ilmiah Dasar Metode Teknik. Bandung: Tarsito 